\title{
The effect of endophyte in perennial ryegrass and tall fescue on red and blackheaded pasture cockchafers
}

\author{
B.M. WATSON \\ P.O.Box 64, Toora Victoria Australia 3962 \\ yas@net-tech.com.au
}

\begin{abstract}
Perennial ryegrass (Lolium perenne L.) and tall fescue (Festuca arundinacea Schreb.) are two of the most productive pasture species grown to feed livestock in Australia. The larvae of redheaded (RHC) (Adoryphorus couloni Burmiester) and blackheaded (BHC) (Accrosidius tasmaniae Hope) cockchafer cause significant damage to these pastures in Australia. If alkaloids produced by endophyte associations could reduce this impact, economic gains would be made. A pot experiment and then a proof of concept seed feeding experiment were undertaken to test the resistance of perennial ryegrass and tall fescue to cockchafer larvae. The objective was to allow larvae to feed on endophyte infected plants, assuming insecticidal alkaloids would be produced and on nil endophyte plants as controls. The plants in the pot experiment were tested for presence or absence of alkaloid endophyte but not for concentration or location in plant parts prior to larvae being introduced. In the seed feeding experiment seed fed to larvae was tested for all known alkaloid concentrations and profiles. The weight difference and mortality of third instar larvae and weight difference of plant root and shoot were measured in the pot experiment. The weight difference and mortality of the third instar larvae and the number and weight of seeds consumed were measured in the seed feeding experiment. There was no significant effect of endophyte treatments on the cockchafer weight change or mortality in either the perennial ryegrass or tall fescue pot or seed feeding experiments. There was a significant difference between cockchafer species $(\mathrm{P}<0.001)$ with the larger redheaded larvae consuming more than the blackheaded larvae. It is concluded in both experiments that red and blackheaded cockchafers are not sensitive to endophyte in perennial ryegrass and tall fescue. Endophyte infection can be harmful to livestock and manipulation in plant cultivars can provide insect resistance and drought tolerance which is still a valuable attribute in all areas where cockchafers are not a problem. However, even when cockchafers damage plants, endophyte infection may enhance the ability of these cultivars to recover.
\end{abstract}

Keywords: endophytes, cockchafers, perennial ryegrass, tall fescue

\section{Introduction}

Red (RHC) and blackheaded (BHC) cockchafers can cause considerable damage to both seedling, and mature, ryegrass and tall fescue plants in Australia, the former by harvesting the roots and the latter the shoots. Endophyte associations with grasses are known to enhance pasture establishment, productivity and persistence. However there are issues of animal health problems, particularly ryegrass staggers and fescue toxicosis attributed to toxins in wild type endophytes. The introduction of novel or safe endophyte associations, along with endophyte-free (Nil) will provide valuable safe grazing options. New Zealand has relied on a strong Australian demand for forage seed, and the importance of this work to Australian farmers was the reason for undertaking extensive and thorough experiments with both plants and seed to determine if any deterrent effect from alkaloids produced by endophytes could be detected.
Concentration of endophyte mycelia is highest in the tillers at the base of the plant and in the seed. Ergovaline levels in wildtype infected plants are lower in the winter in samples taken from perennial ryegrass pastures in Australia and New Zealand and peramine levels highest in summer and autumn (Woodburn et al. 1993). Pasture cultivars of perennial ryegrass and tall fescue are available without endophyte and in the areas where there is little risk of drought and minimal insect pressure these are a viable option.

The presence of novel endophytes in perennial ryegrass and tall fescue has been shown to deter several insect species (Ball et al. 1994; Ball et al. 1997; Popay 1997; Popay \& Wyatt 1995; Rowan \& Gaynor 1986). In other insect species, including Scarabaeidae, effects have been shown on larval weight, feeding and mortality with endophyte-infected perennial ryegrass and tall fescue (Prestidge \& Ball 1993; West \& Gwinn 1993) but no information is available for cockchafers.

The aim of these experiments was to determine if there were measurable effects of novel or wild-type endophyte infected ryegrass and tall fescue on $\mathrm{RHC}$ and $\mathrm{BHC}$ larvae. By measuring weight change of larvae and final weight of plants and plant parts after feeding, deterrence or toxicity to the insect in relation to the plants consumed could be determined. In addition, because there are high concentrations of alkaloids produced by endophytes in seed, the consumption of seed containing various endophytes was also investigated.

\section{Methods}

Pot experiments

To test if wild-type or novel endophytes deterred pasture cockchafers a pot experiment was established in the autumn of 2003. The endophyte treatments used in perennial ryegrass cv. Grasslands Samson were: no endophyte (Nil) and infected with wild-type or AR37 novel endophyte. The tall fescue cultivar/ endophyte associations were Grasslands Advance (Continental summer active) Nil and infected with AR542 and Grasslands Flecha (Mediterranean summer dormant) Nil and AR542.

Table 1 Effects of endophyte in perennial ryegrass cv. Samson on difference between initial and final larval weight for red $(\mathrm{RHC})$ and blackheaded $(\mathrm{BHC})$ cockchafers.

\begin{tabular}{llll}
\hline $\begin{array}{l}\text { Endophyte } \\
\text { treatment }\end{array}$ & RHC & BHC & Mean \\
\hline Nil & 0.574 & 0.442 & 0.508 \\
AR37 & 0.566 & 0.442 & 0.504 \\
Wild & 0.580 & 0.442 & 0.511 \\
Mean & 0.573 & 0.442 & 0.508 \\
Lsd $_{\text {05 Endophyte }}$ & & 0.027 & \\
Lsd $_{\text {05 Cockchafer }}$ & & 0.086 & \\
Lsd $_{\text {05 Endophyte and cockchafer }}$ & 0.075 & \\
\hline
\end{tabular}


Table 2 Effects of endophyte type in perennial ryegrass cv. Samson on plant shoot and root weight without cockchafers $(\mathrm{NC})$ or after feeding by red (RHC) and blackheaded $(\mathrm{BHC})$ cockchafers.

\begin{tabular}{|c|c|c|c|c|c|c|c|c|}
\hline \multirow{2}{*}{$\begin{array}{l}\text { Endophyte } \\
\text { treatment }\end{array}$} & \multicolumn{5}{|c|}{-------- Shoot weight (g) -------- } & \multicolumn{3}{|c|}{---- Root weight (g) -------- } \\
\hline & $\mathrm{NC}$ & $\mathrm{RHC}$ & $\mathrm{BHC}$ & Mean & $\mathrm{NC}$ & $\mathrm{RHC}$ & $\mathrm{BHC}$ & Mean \\
\hline Nil & 1.803 & 2.298 & 1.998 & 2.033 & 2.830 & 3.560 & 2.020 & 2.810 \\
\hline AR37 & 1.537 & 2.236 & 1.819 & 1.846 & 1.910 & 2.240 & 1.460 & 1.870 \\
\hline Wild type & 1.985 & 1.908 & 1.932 & 1.942 & 2.670 & 1.950 & 1.580 & 2.060 \\
\hline Mean & 1.775 & 2.148 & 1.916 & 1.946 & 2.470 & 2.580 & 1.690 & 2.250 \\
\hline \multicolumn{2}{|l|}{ Lsd $_{05 \text { Endophyte }}$} & \multicolumn{4}{|l|}{0.459} & \multicolumn{3}{|l|}{0.730} \\
\hline \multicolumn{2}{|c|}{ Lsd $_{05 \text { Cockchafer }}$} & \multicolumn{4}{|l|}{0.459} & \multicolumn{3}{|l|}{0.730} \\
\hline \multicolumn{2}{|c|}{ Lsd $_{05}$ Endophyte and cockchater } & \multicolumn{4}{|l|}{0.794} & \multicolumn{3}{|l|}{1.265} \\
\hline
\end{tabular}

Table 3 Effects of endophyte type in tall fescue cv Advance and Flecha on change in larvae weight (initial minus final) for red $(\mathrm{RHC})$ and blackheaded $(\mathrm{BHC})$ cockchafers.

\begin{tabular}{|c|c|c|c|c|c|c|c|}
\hline \multirow[b]{2}{*}{ Fescue } & \multicolumn{2}{|c|}{$\mathrm{RHC}$} & \multicolumn{2}{|c|}{$\mathrm{BHC}$} & \multicolumn{2}{|c|}{ Mean } & \multirow[t]{2}{*}{ Mean } \\
\hline & Advance & Flecha & Advance & Flecha & Advance & Flecha & \\
\hline Nil & 0.479 & 0.472 & 0.406 & 0.392 & 0.442 & 0.432 & 0.437 \\
\hline AR542 & 0.477 & 0.487 & 0.399 & 0.403 & 0.438 & 0.445 & 0.441 \\
\hline Mean & 0.478 & 0.479 & 0.402 & 0.397 & 0.440 & 0.438 & \\
\hline Mean & \multicolumn{2}{|c|}{0.479} & \multicolumn{2}{|c|}{0.400} & \multicolumn{2}{|c|}{0.439} & \\
\hline Lsd $_{05}$ Endophyte & & & & 0.023 & & & \\
\hline Lsd $_{05}$ cockchafer & & & & 0.065 & & & \\
\hline Lsd $_{05 \text { Fescue }}$ & & & & 0.024 & & & \\
\hline Lsd $_{05}$ Endophyte a & ockchafer & & & 0.060 & & & \\
\hline
\end{tabular}

Perennial ryegrass and tall fescue seedlings were grown in pots and kept in a shadehouse to exclude other insects. RHC and $\mathrm{BHC}$ were collected from the field and stored in the open, but under roof cover, in moist soil in plastic tubs under pasture clods and animal manure to simulate their natural environment. All plants were at the two to four tiller stages at 13 weeks after planting and were tested for presence or absence of endophyte by the immunoblot procedure (Gwinn et al. 1991; Hahn et al. 2003; Hiatt et al. 1997).

On June 25, the larvae were weighed and two RHC or four $\mathrm{BHC}$ were added to each pot containing the tall fescue plants. Pots were also left without larvae. Pots were then positioned with six rows and six columns replicated three times in three groups and placed in plastic bowls to contain the larvae. On June 26, the larvae were weighed and placed in the perennial ryegrass experiment in which 36 plants of each cultivar were allocated to three groups with all pots placed individually in plastic bowls to contain the larvae.

On August 9 the tall fescue experiment concluded when plants were 24 weeks old. On August 10, the perennial ryegrass experiment concluded with these plants being 22 weeks old. All larvae were retrieved, weighed and counts recorded. The plants were then carefully removed from the soil medium and thoroughly washed and then dried. The shoots and roots were then separated with a scalpel. These plant parts were individually weighed (Shinko $600^{\mathrm{TM}} \pm 0.01 \mathrm{~g}$ ), bagged and taken for freeze-drying to preserve alkaloids.

\section{No-choice seed experiments}

As a proof of concept that these endophytes can deter cockchafer feeding, no-choice seed feeding experiments with RHC and BHC were conducted in 2004. For the perennial ryegrass experiment the same treatments described in the pot experiment were used. For the tall fescue experiments, Grasslands Advance Nil endophyte and with AR542 novel endophyte and Grasslands Flecha Nil endophyte and with AR542 novel endophyte were used. In addition Jesup (Nil and Wild type) from the USA, and New Zealand roadside tall fescue (Nil and Wild-type) were included in the experiment.

Both the $\mathrm{RHC}$ and $\mathrm{BHC}$ were fed with the three perennial ryegrass treatments. In the tall fescue experiments, all eight cultivar/endophyte associations were fed to RHC but only four, Grasslands Advance Nil and AR542 and Grasslands Flecha Nil and AR542 were fed to BHC. Larvae were weighed and then placed individually into six cell multiwell culture plates which had been previously weighed (Shinko $600^{\mathrm{TM}} \pm 0.01 \mathrm{~g}$ ), and 
Table 4 Effects of endophyte type in tall fescue cv Advance and Flecha on shoot weight without cockchafer larvae (NC) or with redheaded $(\mathrm{RHC})$ or blackheaded cockchafer.

\begin{tabular}{|c|c|c|c|c|c|c|c|c|c|}
\hline \multirow[b]{2}{*}{ Fescue } & \multicolumn{2}{|c|}{ NC } & \multicolumn{2}{|c|}{$\mathrm{RHC}$} & \multicolumn{2}{|c|}{$\mathrm{BHC}$} & \multicolumn{2}{|c|}{ Mean } & \multirow[t]{2}{*}{ Mean } \\
\hline & Advance & Flecha & Advance & Flecha & Advance & Flecha & Advance & Flecha & \\
\hline Nil & 2.243 & 1.171 & 1.726 & 1.154 & 1.788 & 1.371 & 1.919 & 1.232 & 1.576 \\
\hline AR542 & 1.737 & 1.592 & 1.978 & 0.769 & 1.830 & 1.117 & 1.848 & 1.159 & 1.504 \\
\hline Mean & 1.990 & 1.382 & 1.852 & 0.962 & 1.809 & 1.244 & 1.884 & 1.196 & \\
\hline Mean & \multicolumn{2}{|c|}{1.686} & \multicolumn{2}{|c|}{1.407} & \multicolumn{2}{|c|}{1.526} & \multicolumn{2}{|c|}{1.540} & \\
\hline \multicolumn{3}{|c|}{ Lsd $_{05}$ Endophyte } & \multicolumn{2}{|l|}{0.339} & & & & & \\
\hline \multicolumn{3}{|c|}{ Lsd $_{05}$ cockchater } & \multicolumn{2}{|l|}{0.415} & & & & & \\
\hline \multicolumn{3}{|c|}{ Lsd $_{05 \text { Fescue }}$} & \multicolumn{2}{|l|}{0.339} & & & & & \\
\hline \multicolumn{3}{|c|}{ Lsd $_{05}$ Endophyte and cockchafer } & 0.586 & & & & & & \\
\hline
\end{tabular}

Table 5 Effects of endophyte type in tall fescue cv Advance and Flecha on root weight without cockchafer larvae (NC) or with redheaded $(\mathrm{RHC})$ or blackheaded cockchafer.

\begin{tabular}{|c|c|c|c|c|c|c|c|c|c|}
\hline \multirow[b]{2}{*}{ Endophyte } & \multicolumn{2}{|c|}{ NC } & \multicolumn{2}{|c|}{$\mathrm{RHC}$} & \multicolumn{2}{|c|}{$\mathrm{BHC}$} & \multicolumn{2}{|c|}{ Mean } & \multirow[t]{2}{*}{ Mean } \\
\hline & Advance & Flecha & Advance & Flecha & Advance & Flecha & Advance & Flecha & \\
\hline $\mathrm{Nil}$ & 1.912 & 0.882 & 1.337 & 0.733 & 1.776 & 0.957 & 1.675 & 0.857 & 1.226 \\
\hline AR542 & 1.561 & 1.423 & 1.898 & 0.549 & 1.500 & 0.821 & 1.653 & 0.931 & 1.292 \\
\hline Mean & 1.737 & 1.153 & 1.617 & 0.641 & 1.638 & 0.889 & 1.664 & 0.894 & \\
\hline Mean & \multicolumn{2}{|c|}{1.445} & \multicolumn{2}{|c|}{1.129} & \multicolumn{2}{|c|}{1.263} & \multicolumn{2}{|c|}{1.279} & \\
\hline Lsd $_{05}$ Endophyte & & & \multicolumn{2}{|l|}{0.375} & & & & & \\
\hline Lsd $_{05 \text { Cockchafer }}$ & & & \multicolumn{2}{|l|}{0.459} & & & & & \\
\hline Lsd $_{05 \text { Fescue }}$ & & & \multicolumn{2}{|l|}{0.375} & & & & & \\
\hline \multicolumn{3}{|c|}{ Lsd $_{05}$ Endophyte and cockchafer } & 0.650 & & & & & & \\
\hline
\end{tabular}

clearly identified. The lids were then fitted and the plates placed on shelves in a cabinet.

The perennial ryegrass experiment with $\mathrm{RHC}$ commenced on June 52004 and was assessed on June 8, 13, 20, 25 and 30. At each assessment remaining seed was counted, trays were weighed and larval survival recorded before more seed was added and each tray was reweighed. The final weight and survival of larvae and the weight and count of seed and tray recorded on the July 7. The experiment with BHC commenced on June 14 and seed was added on the June 19, 21, 27 and July 1 and 7 with the final records on July 14.

The tall fescue experiments with RHC commenced on the July 22 and seed were added on July 25 and 31, August 5 and 8, with the final record of weight and survival of larvae and the weight and count of seed and tray on August 20. The experiment with BHC commenced on the July 25 with seed added on July 31 and August 5 and 8 and the final records were taken on August 20.

\section{Results}

\section{Pot experiments}

There was no significant effect of endophyte on the weight change of RHC or BHC larvae consuming ryegrass plants $(\mathrm{P}>0.05$, Table 1$)$.

There were no significant interactions between endophyte treatment and cockchafer species for plant shoot or root weights
(Table 2). There were no significant differences between treatments for any of the variables in the perennial ryegrass experiment except for the main effect of cockchafer species on initial larval weights $(\mathrm{P}<0.001)$ for which $\mathrm{RHC}$ was greater than BHC. There were no significant main effects of treatment on ryegrass shoot weights, but root weights were affected by both endophyte treatment and cockchafer species. Root weight at harvest was significantly less in the novel endophyte treatment (mean $1.87 \mathrm{~g}$ ) than the nil treatment $(2.81 \mathrm{~g})$ with the wild-type intermediate $(2.07 \mathrm{~g})(\mathrm{P}<0.05)$. Root weight in the presence of $\mathrm{BHC}$ (mean $1.69 \mathrm{~g}$ ) was less than root weight without larvae or with RHC (2.47 $\mathrm{g}$ and $2.58 \mathrm{~g}$ respectively, $\mathrm{P}<0.05)$. Root fraction data showed no apparent interactions.

There was no significant effect of endophyte or tall fescue cultivar on the weight change of larvae consuming either Advance summer active or Flecha winter active tall fescue $(\mathrm{P}>0.05)$ (Table $3)$. In the tall fescue experiment cockchafers initial weights were also significantly different $(\mathrm{P}<0.001)$ between the two species as seen in the perennial ryegrass experiment.

There was a significant difference between Grasslands Advance summer active tall fescue and Grasslands Flecha summer dormant tall fescue in the shoot (Table 4) and root (Table 5) weights of plant parts at harvest. The summer dormant Flecha, had consistently less plant material than the summer active Advance. The Flecha plants at no time grew as vigorously as the Advance plants. Root fraction data show no significant 
Table 6 Effects of endophyte type in perennial ryegrass cv. Samson on difference between initial and final larval weight and weight of seed eaten for red $(\mathrm{RHC})$ and blackheaded $(\mathrm{BHC})$ cockchafers.

\begin{tabular}{lllll}
\hline Endophyte treatment & \multicolumn{2}{l}{ Larval weight difference $(\mathrm{g})$} & \multicolumn{2}{l}{ Weight of seed eaten (g) } \\
& $\mathrm{RHC}$ & $\mathrm{BHC}$ & $\mathrm{RHC}$ & $\mathrm{BHC}$ \\
\hline Nil & -0.820 & -0.440 & 2.244 & 1.492 \\
AR37 & -0.576 & -0.470 & 2.328 & 1.382 \\
Wild type & -0.448 & -0.486 & 2.214 & 1.312 \\
Mean & -0.615 & -0.465 & 2.262 & 1.377 \\
LSD $_{05}$ & 0.391 & 0.116 & 0.418 & 0.234 \\
\hline
\end{tabular}

Table 7 Effects of endophyte type in cv. Advance, Flecha, Jesup and New Zealand roadside tall fescue on difference between initial and final larval weight and weight of seed eaten for red (RHC) and blackheaded (BHC) cockchafers.

\begin{tabular}{|c|c|c|c|c|c|c|c|c|}
\hline \multirow{3}{*}{$\begin{array}{l}\text { Endophyte } \\
\text { treatment }\end{array}$} & \multicolumn{4}{|c|}{ Larvae weight difference (g) } & \multicolumn{4}{|c|}{ Seed eaten $(\mathrm{g})$} \\
\hline & \multicolumn{2}{|c|}{$\mathrm{RHC}$} & \multicolumn{2}{|c|}{$\mathrm{BHC}$} & \multicolumn{2}{|c|}{$\mathrm{RHC}$} & \multicolumn{2}{|c|}{$\mathrm{BHC}$} \\
\hline & Nil & Endo & Nil & Endo & Nil & Endo & Nil & Endo \\
\hline Advance & -0.705 & -0.565 & -0.490 & -0.424 & 0.935 & 1.005 & 0.799 & 0.779 \\
\hline Flecha & -0.775 & -0.782 & -0.509 & -0.539 & 0.910 & 0.845 & 0.785 & 0.839 \\
\hline Jesup & -0.950 & -0.547 & & & 0.788 & 1.087 & & \\
\hline NZ roadside & -0.558 & -0.685 & & & 1.145 & 0.930 & & \\
\hline Mean & -0.700 & & -0.495 & & 0.956 & & 0.796 & \\
\hline LSD $_{05 \text { Cultivar }}$ & 0.254 & & 0.130 & & 0.215 & & 0.225 & \\
\hline LSD $_{05 \text { Endophyte }}$ & 0.180 & & 0.184 & & 0.152 & & 0.319 & \\
\hline LSD $_{05}$ Cultivar and endophyte & 0.359 & & 0.238 & & 0.304 & & 0.411 & \\
\hline
\end{tabular}

interactions. Analysis of number of larvae applied and number recovered in both experiments showed no effect of treatment on mortality of RHC (1\%) and BHC (2\%).

\section{No-choice seed experiments}

Larvae of both $\mathrm{RHC}$ and $\mathrm{BHC}$ species lost weight over the duration of both the perennial ryegrass and tall fescue experiments and neither the amount of weight lost nor survival was affected by endophyte type in cv. Samson $(\mathrm{P}>0.05)$ (Table $6)$ or in cv. Advance, Jesup, Flecha or New Zealand roadside $(\mathrm{P}>0.05)$ (Table 7).

There was no effect of endophyte treatment on the weight of seed consumed by cockchafers. Counts of larvae in both the perennial ryegrass and tall fescue experiments showed larvae died progressively during the captive feeding. In the perennial ryegrass experiment losses of larvae were $28 \%$ and $20 \%$ for the RHC and $\mathrm{BHC}$ respectively. In the tall fescue experiment losses of larvae were $20 \%$ and $18 \%$ respectively.

\section{Discussion}

The presence of endophyte in a plant is determined from the seed but the growth of the fungus may not extend to all plant parts. The feeding voracity of cockchafer larvae at the time when new seedlings emerge, and also as adult plants are responding to autumn rains, is seen as a significant issue in pasture persistence, establishment and production. Perennial ryegrass sown in Australian pastures has been mainly high in wild-type endophytes while tall fescue sowings have usually been endophyte-free to avoid animal health issues. Australian native pastures are not known to be infected with Neotyphodium spp. and pasture cockchafers are an Australian native insect that presumably coexisted in a mutual relationship with native tufted grasses.

Pasture cockchafers are only one of many predators that effect plant establishment and survival and this work is following on from known success against other similar shoot feeding insects (Ball et al. 1994; Dahlman et al.1997; Popay et al. 2005; Popay et al. 2004; Popay et al. 2003) and root feeders (Popay et al. 2004).

Endophytes in both grass species in the pot experiment showed no effect of endophyte on pasture cockchafers so a proof of concept experiment to measure effect of endophytes was undertaken. The pot experiment results however supported the theory that endophytes can enhance recovery after insect attack by allocation of nutrient to stimulate plant growth above or below ground and decrease above ground feeding (Omacini et al. 2005). It was concluded therefore that a no choice seed feeding experiment was required using similar techniques to recent work done in New Zealand by (Popay \& Lane; Popay et al. 2003) with some modifications to suit these two cockchafer lifestyles.

The no choice seed experiment as a proof of concept was the only option where live material could be used with identified levels of alkaloids. Other researchers have used elevated levels not found in natural associations to prove this concept, but then further research to achieve these levels in perennial ryegrass and tall fescue would need to be undertaken. Lolitrem B has minor effects on insects but ergovaline, peramine and lolines provide greater resistance (Hume \& Cosgrove 2005). These experiments 
found, ergovaline, peramine lolines and janthitrems did not affect RHC and BHC larval feeding, weight or mortality.

Tall fescue has a large root system which can withstand some active feeding of pest insects. The presence of lolines is thought to enhance seedling survival. In North America the root feeding white grub of Japanese beetle (Popillia japonica Newman) was reported by (Patterson et al. 1992) to be deterred by lolines at concentrations of $250 \mu \mathrm{g} / \mathrm{g}$. Similar experimental research was conducted in New Zealand with grass grub feeding on crude extracts of milled tall fescue seed (Popay \& Lane 2000). These researchers showed that lolines would affect grass grub feeding and were present in the plant roots. These experiments reported here found that lolines did not affect RHC and BHC larvae feeding, weight or mortality.

Further research may focus on insects in earlier instar stages and this could be done feeding seed. The larvae may also have a mechanism for metabolising alkaloids thereby preventing toxicity suggesting work looking at the digestion of alkaloids by measuring concentrations in the faecal pellets of cockchafers to confirm excretion of the toxins in this manner. To do this faecal pellets could be collected from larvae fed with imbibed infected seed and placed on nitrocellulose membrane as described in the immunoblot method. This may show if grass endophytes are excreted by the larvae.

Overall the results provided no evidence to show that RHC and $\mathrm{BHC}$ larvae are affected by alkaloids produced by perennial ryegrass or tall fescue endophyte infections. Acceptance of infected plants and seed by the larvae and survival and weight change over a prolonged time in both the pot experiments and no choice experiments supports this conclusion. The species and the endophyte combination are thought to control insect feeding. In this experiment the combinations were chosen with the presumption that some of the endophyte alkaloids would deter cockchafers. There is, however, mixed findings when reviewing other research results which could explain the lack of treatment effects in the current experiments. The interaction promoting plant survival after larval damage by endophyte protection from other insects and pathogens possibly entering via damaged plant parts needs investigation. If novel endophyte infection can further enhance persistence, productivity and insect resistance while reducing animal toxicity in comparison to wild-type endophyte, the contribution of this research developing a simple method of testing insect resistance by feeding imbibed seed has been worthwhile.

\section{ACKNOWLEDGEMENTS}

Gavin Milne for the original research suggestion and full support from Agricom, David Chapman and Richard Eckard for supervision of each new stage, Alison Popay, David Hume and Wayne Simpson for moral support, design and technical assistance, Michelle Michie at CSIRO for arranging an entomologist, Murray Hannah for biometrics.

\section{REFERENCES}

Ball, O.J-P.; Christensen, M.J.; Prestidge, R.A. 1994. Effect of selected isolates of Acremonium endophyte on adult black beetle (Heteronychus arator) feeding. Proceedings of the 47th New Zealand Plant Protection Conference: 227-231.

Ball, O.J-P.; Miles, C.O.; Prestidge, R.A. 1997. Ergopeptine alkaloids and Neotyphodium lolii-mediated resistance in perennial ryegrass against adult Heteronychus arator (Coleoptera: Scarabaeidae). Journal of Economic Entomology 90: 1382-1391.
Dahlman, D.L.; Siegel, M.R.; Bush, L.P. 1997. Insecticidal activity of $\mathrm{N}$-formylloline. pp. 13-15. In: XVIII International Grasslands Conference, Winnipeg, Canada.

Gwinn, K.D.; Collins Shepard, M.H.; Reddick, B.B. 1991. Tissue print-immunoblot, an accurate method for the detection of Acremonium coenophialum in tall fescue. Phytopathology 81: 747-748.

Hahn, H.; Huth, W.; Schoberlein, W.; Diepenbrock, W. 2003. Detection of the endophytic fungi in Festuca spp. by means of tissue print immunoassay. Plant Breeding 12: 217-222.

Hiatt, E.E.I.; Hill, N.S. 1997. Neotyphodium coenophialum mycelial protein and herbage mass effects on ergot alkaloid concentration in tall fescue. Journal of Chemical Ecology 23: 2721-2736.

Hume, D.E.; Cosgrove, G.P. 2005. Endophyte - what is it and its significance in New Zealand pastoral agriculture. pp. 31-36 In: Proceedings of the 20th NSW Grassland Society. Ed. H.L. Davies, 19-21 July 2005, Orange, New South Wales.

Omacini, M.; Chaneton, E.J.; Ghersa, C.M. 2005. A hierarchical framework for understanding the ecosystem consequences of endophyte-grass symbioses. pp. 141-162. In: Neotyphodium in Cool-Season Grasses. Eds. Roberts, C.A.; West, C.P., Spiers, D.E. Blackwell Publishing, Ames, Iowa.

Patterson, C.G.; Potter, D.A.; Fannin, F.F. 1991. Feeding deterrency of alkaloids from endophyte-infected grasses to Japanese beetle larvae. Entomologia Experimentalis et Applicata 61: 285-289.

Popay, A.J. 1997. Argentine stem weevil response to variable endophyte infection in Grasslands Greenstone ryegrass. Proceedings of the 50th New Zealand Plant Protection Conference: 69-72.

Popay, A.J.; Wyatt, R.T. 1995. Resistance to Argentine stem weevil in perennial ryegrass infected with endophytes producing different alkaloids. Proceedings of the 48th New Zealand Plant Protection Conference: 229-236.

Popay, A.J.; Lane, G.A. 2000. The effect of crude extracts containing loline alkaloids on two New Zealand insect pests. pp. 471-475. In: 4th International Neotyphodium/Grass Interactions Symposium. Eds. Paul, V. H.; Dapprich, P. D. Soest, Germany.

Popay, A.J.; Townsend, R.J.; Fletcher, L.R. 2003. The effect of endophyte (Neotyphodium uncinatum) in meadow fescue on grass grub larvae. New Zealand Plant Protection 56: 123-128.

Popay, A.J.; Silvester, W.B.; Gerard, P.J. 2004. New endophyte isolate suppresses root aphid, Aploneura lentisci, in perennial ryegrass. pp. 317 . In: 5th International Symposium on Neotyphodium/Grass Interactions. Eds. Kallenbach, R.; Rosenkrans, C. J.; Lock, T. R. Fayetteville, Arkansas.

Popay, A.J.; Jensen, J.G.; Cooper, B.M. 2005. The effect of nontoxic endophytes in tall fescue on two major insect pests. Proceedings of the New Zealand Grassland Association 67: 169-173.

Prestidge, R.A.; Ball, O.J.-P. 1993. The role of endophytes in alleviating plant biotic stress in New Zealand. pp. 141-151. In: Second International Symposium on Acremonium grass interactions. Eds. Hume, D.E.; Latch, G C M.; Easton, H.S. AgResearch, Palmerston North, New Zealand.

Rowan, D.D.; Gaynor, D.L. 1986. Isolation of feeding deterrents against Argentine stem weevil from ryegrass infected with the endophyte Acremonium loliae. Journal of Chemical Ecology 12: 647-658.

West, C.P.; Gwinn, K.D. 1993. Role of Acremonium in drought, pest, and disease tolerances of grasses. pp. 131-140 In: 
Proceedings of the 2nd Symposium on Acremonium/Grass Interactions: Plenary Papers. Eds. Hume, D.E.; Latch, G.C.M.; Easton, H.S. Palmerston Nth, New Zealand.

Woodburn, O.J.; Walsh, J.R.; Foot, J.Z.; Heazlewood, P.G. 1993. Seasonal ergovaline concentrations in perennial ryegrass cultivars of differing endophyte status. In: Proceedings of the 2nd Symposium on Acremonium/Grass Interactions. Eds. Hume, D.E.; Latch, G.C.M.; Easton, H.S. Palmerston Nth, New Zealand. 